\title{
The Impact of Odors
}

M. V. Jokl

The odor microclimate is formed by gaseous airborne components perceived either as an unpleasant smell or as a pleasant smell. Smells enter the building interior partly from outdoors (exhaust fumes - flower fragrance) and partly from indoors (building materials, smoking cigarettes - cosmetics, dishes). They affect the human organism through the olfactory center which is connected to the part of brain that is responsible for controlling people's emotions and sexual feelings: smells therefore participate to a high level in mood formation. The sense of smell diminishes slowly in people over the age of 60, but all female age categories have a better sense of smell than males. Smell is extremely sensitive, e.g., during pregnancy, or if an illness is coming. Bad smells cause a decrease in human performance, loss of concentration, and loss of taste. Sweet smells have a positive impact on human feelings and on human performance. Criteria for odor microclimate appraisal are presented (concentration limits of $\mathrm{CO}_{2}, \mathrm{TVOC}$, plf, decipol, decicarbdiox, decitvoc).

Keywords: odors, microenvironment, hygiene, indoor air quality, microclimate.

\section{Introduction}

The odor microclimate is the constituent of the microenvironment characterized by odor agents occurring in a given space in a building interior and affecting the total state of the human organism [6].

Odor agents (odors) are gas components in the atmosphere perceived as pleasant or unpleasant, bad smells. They are organic or inorganic in nature, usually produced by man himself, or as a result of his activity, or else are released from building materials. Toxic odors are not a part of the odor microclimate - they are included in the toxic microclimate.

There is an increasing tendency for odors to occur in the interiors of buildings [7].

\section{Sources of odors}

The sources of unpleasant and pleasant odors are as follows:

\subsection{The sources of unpleasant odors}

The unpleasantness of an odor is characterized by the so-called Hedonic Tone, i.e., by the subjective feelings of human beings [5], [12].

There are five principal types of odors according to the Zwaardermarker scale:
1. Etheric (human smells),

2. Aromatic (smells of ripe fruit decay),

3. Isovalerate (smells from smoking tobacco, smells of animal sweat),

4. Rancid (smells of milk products),

5. Narcotic (smells of protein decay and the smell of tobacco).

Odors enter the microenvironment from outdoor as well as indoor sources, as a consequence of human activity, and after being released from building materials, especially from insulations, coatings, and from chemicals for wood protection (Fig. 1).

Fifty to $80 \%$ of odors enter the room from outdoors products of combustion engines (oxides of nitrogen and sulphur, carbon monoxide, sulphates and compounds of nitrogen, sulphur and carbon), air pollution by industrial plants, and smoke from power stations and boiler rooms.

The indoor air treatment system may cause problems with tobacco smoke (if smoking is allowed in air-conditioned rooms) and oil decay (if filters are not cleaned properly).

Formaldehyde is released from some building materials plywood, chipboard, parquets, varnishes and other paintwork, wallpaper (treated with artificial resin against abrasion) and from cork flooring and linings.

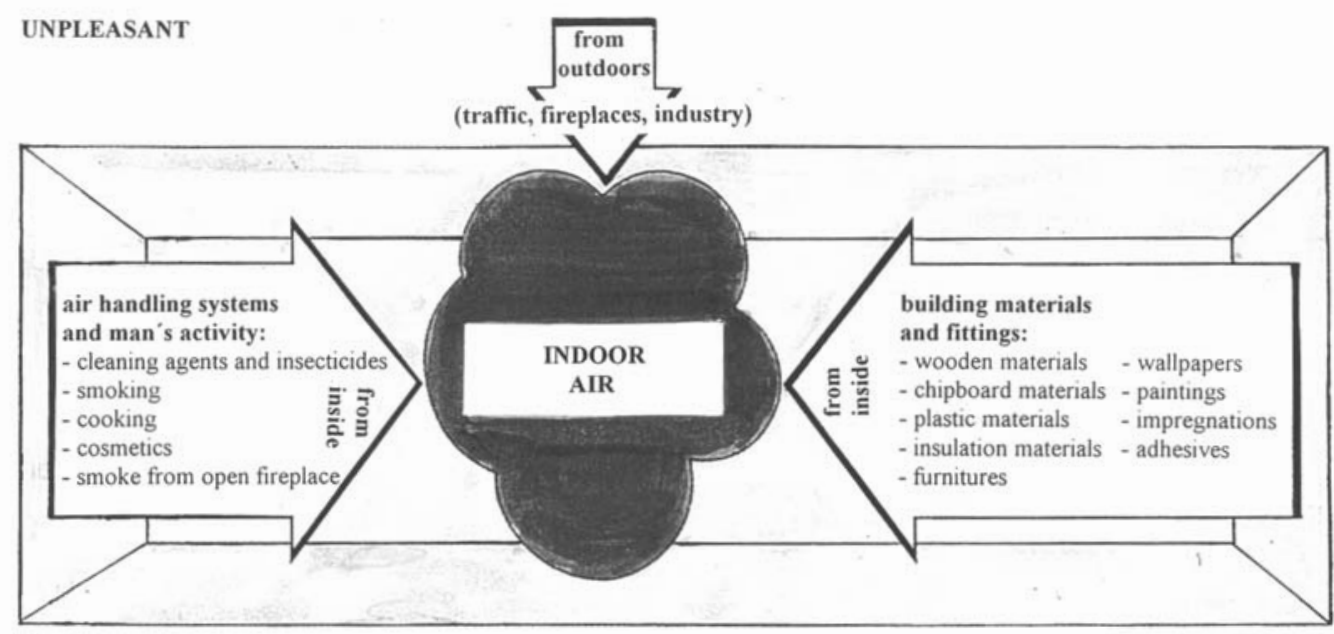

Fig. 1: Sources of unpleasant odors in a building interior 


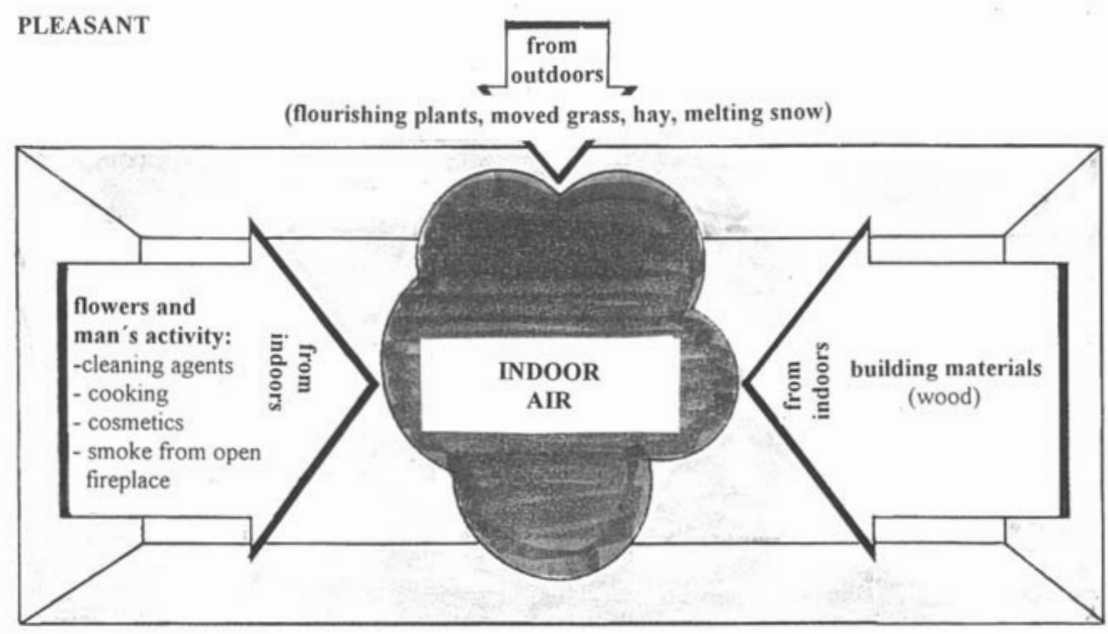

Fig. 2: Sources of pleasant odors in a building interior

Pentachlorphenol (PCP), lindane and pyrethroid (occasionally permethrine) are given off by impregnating preparations. Isocyanate (used as a binder) is produced by non-formaldehyde chipboards. Petroleum spirit and xylol, organic solvents, are released from paints based on alkyde resins, insert space glykoether is released from acrylate paints, isocyanate from polyurethane materials, isoaliphate from paints based on natural resins. Chloroprene is produced by adhesives based on artificial rubber, isocyanate (epichlorhydrine or ethylester of cyanoacrylate acid) is released from acrylate glue. Dioxine and furane are produced by burning PVC. Surprisingly, nothing is released from new floorings based on polyolefin.

During human activity, various body smells are produced (acetone, isoprene); smoke from cigarettes, cigars and pipes is produced (pyridine), and there are odors from cosmetics (an inversion can cause serious unpleasantness), cleaning chemicals, and from rubbish. (Inversion is the change of a pleasant odor into an unpleasant one, i.e., bad smell into sweet one or vice versa, as a result of one odor mixing with another, or as a result of a change concentration.)

Mostly volatile organic compounds (VOC - Volatile organic compounds - are defined by WHO as having melting points ranging from 50 to $260{ }^{\circ} \mathrm{C}$ ) are produced. The complex of VOCs (without formaldehyde) produced by human beings within a building, building materials and other sources is referred to as TVOC (Total Volatile Organic Compounds).

Cigarette smoking causes a special problem. Most people perceived it negatively, as a bad smell threatening their health; the response of former smokers seems to be the most sensitive. Smoking, especially intensive and long-term, causes narrowing of veins, nervousness, damage to breathing passages, a decrease in the differentiation ability of the olfactory and taste cells, damage to the lungs by tar and other harmful combustion products, leading to tumors, and so on. It is supposed that smoking one cigarette shortens a human life by seven (according to some specialists even by eleven) minutes. To call a cigarette a nail in one's coffin seems to be quite realistic. Recent studies indicate that tobacco smoke forms part of the toxic microclimate.

\subsection{Sources of pleasant odors}

From outdoors, the smell of blossoming flowers, mown grass, hay and melting snow comes into the interior of a building (Fig. 2).

Indoors, flowers and man-made aromas (cosmetics and detergents, smoke from an open fireplace) are sources of pleasant smells. Even some building materials (e.g., wood) are perceived as pleasant.

What is perseived as an unpleasant odor by some may be perceived as pleasant by others. This can be by matter of personal experience very often: e.g., smoke from an open fireplace induces a feeling of comfort (e.g., based on the smell of smoked sausages) for one person and a feeling only of smoke only for another (having no experience of an open fireplace).

The history of pleasant aromas is very long. They have been used by ladies to make themselves more attractive, and also for other purposes: e.g., a smoke clock was used by the Japanese in the Middle Ages (there was a different smell for each hour).

\section{The impact of odors on man}

The principal question concerns the impact of smells on the human organism.

A schematic representation of the smell organ is shown in Fig. 3a, with a picture in Fig. 3b [15].

Inhaled air passes the nasal shells in the olfactory zone; they are covered with smell cells with mucous membranes on their surface. Odoriferous substances have to come into contact with a mucous membrane, if smell perception is to be evoked. Only about $1 \%$ of the inhaled molecules come in contact with smell cells, producing electric impulses through the bulbus olfactorius to the smell center, which is in the front part of the brain (rhinencephalon), where they are processed. The electroolfactogram (EOG), i.e., the electrical activity registration, registers an increase with the odor concentration.

The part of the brain dealing with smell perception (bulbus) is located above the nose in the center of the fore- 


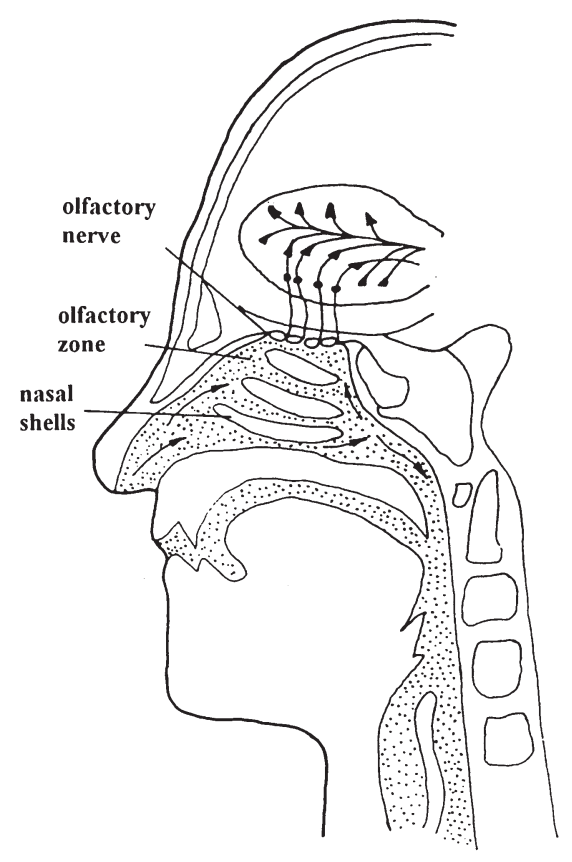

a)

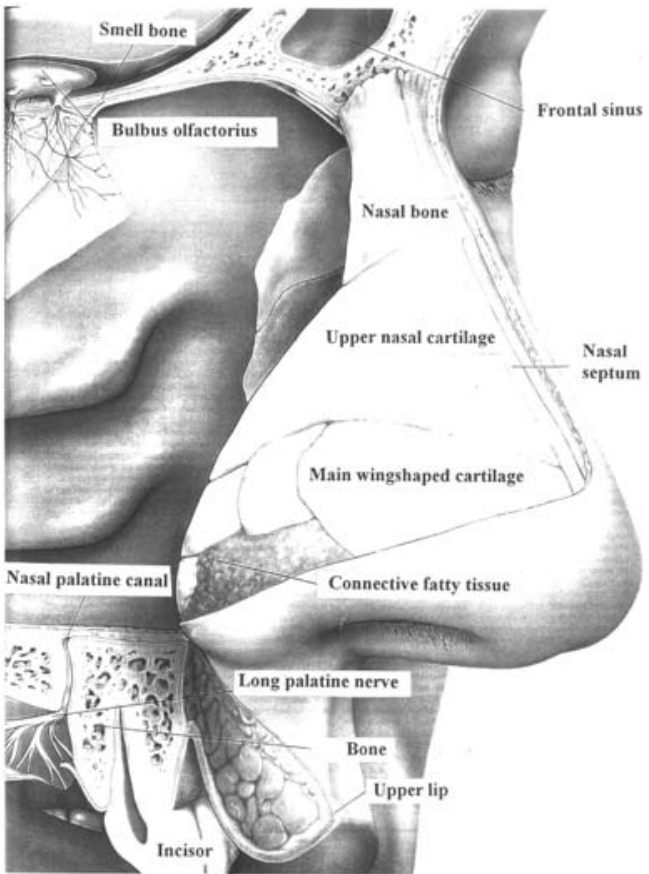

b)

Fig. 3: The human olfactory organ (3a- scheme, 3b- anatomical picture)

head. Most of the nervous pathways from the olfactory bulls end in the oldest (from the evolutionary point of view) area of the central brain, which is responsible for controlling emotional and sexual reactions. It is supposed, on the basis of this evidence, that smells participate to a high extent in the formation of moods. For examples it has been proved that if somebody links his relaxation with a sea smell, then a sea

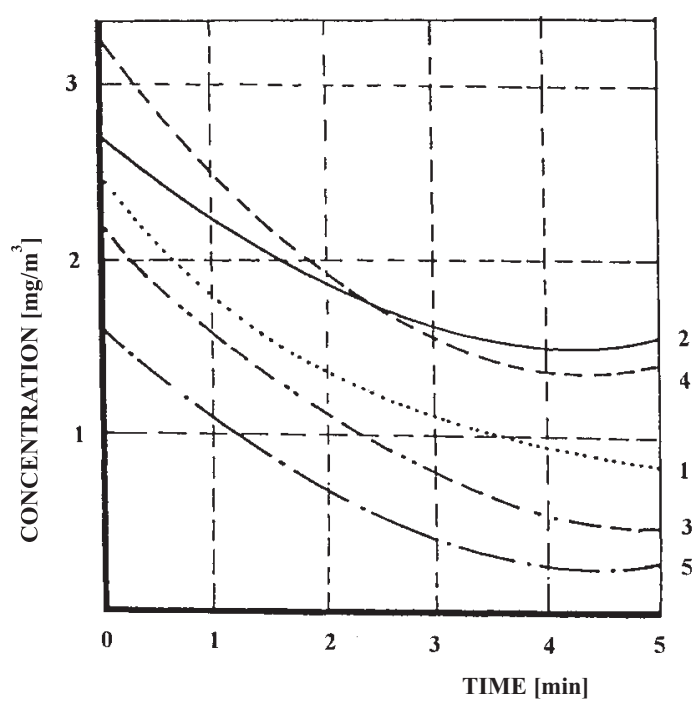

Fig. 4: Odor perception over a period of time. There are five types of odors according to the Zwaardermarker scale: 1. Etheric (human smells),

2. Aromatic (smells of ripe fruit decay),

3. Isovalerate (smells from smoking tobacco, smells of animal sweat),

4. Rancid (smells of milk product),

5. Narcotic (smells of protein decay and the smell of tobacco). smell (without the sea) or the smell of sea salt is sufficient for him to relax.

The perceived odor concentration increases only to the moment of mucous (lipidus doublelayer with odor receivers) saturation, and after that there is no response even to a great increase in the odor. On the contrary, the odor perception level decreases in the course of time, and after 5-15 minutes stabilizes at a minimal value (Fig. 4) as a result of the short time odor adaptation caused by fatigue [10], [11]. The odor perception is recovered rapidly after removal of the odor.

Long-term odor adaptation depending on age also exists. Based on an analysis of the ability to smell of 1955 subjects (1158 women and 797 men aged between 5 and 99), it was found at the Clinical Center for Smell and Taste Research at Pennsylvania University that both sexes have the best sense of smell between the ages of 30 and 60; then, between the age of 60 and 80 , the sense of smell deteriorates slowly (at the age of $80,60 \%$ of the subjects had a very bad sense of smell, and $25 \%$ of the subjects smelled almost nothing), and afterwards it decreases rapidly (over the age of 80 , more than $80 \%$ of the subjects had a very bad sense of smell, and $25 \%$ of the subjects smelled almost nothing).

It was also found at the Clinical Center that all categories (at each age) of women have a better sense of smell than men, and also that nonsmokers have a better sense of smell than smokers.

The ability to smell is very sensitive during pregnancy, during nursing, if the sugar content in the blood is increased, during kidney inflammation, during neuralgic pains (hemicania), and before any coming illness.

Odor perception can be very individual: Johann Wolfgang Goethe complained in one of his letters that the air liked by Schiller impacted on him like a poison. Schiller's favorite was the smell of rotten apples, which could even be found in the drawer of his desk. 


\subsection{The impact of negative odors on man}

Odors do not threaten human health but they impact on man's performance, concentration, taste, and sensation of well-being. Odors are removed from the atmosphere for psychological reasons, and also economic and hygienic reasons, because they often indicate increased contamination of the microenvironment by microbes. Long-term exposure can lead to anxiety, depression and chronical fatigue.

The smell of mold, humidity, stagnant water and mice can produce feelings of derangement, depression, and headachs. Various coatings, oils, photomaterials, and some laundry agents, referred to as smells of civilization, are the worst; they produce a bad mood, feelings of anger and disturbance in $80 \%$ of subjects.

The smell of lilies and orchids make subjects feel chilly, and even produce stupefaction in some of them.

The odor of disinfectant and of some strong aromatic medications impact subjects in the same way, especially women.

\subsection{The impact of positive odors on man}

Pleasant odors are attracting increasing interest, because they can have a positive way effect on people's feelings and performance.

The impact of odors on people was estimated by Stanford and Reynolds on the basis of experiments on 5000 subjects aged 7 to 85 years exposed to 260 smells. Subjects spent one to eight hours in chambers filled with odors of high intensity. Then they were asked for their impressions, and were submitted to medical examination. 260 odors were used: smells of resin, hay, herbs, odors of eighty perfumes, various cosmetics, fresh bread, baked meat, cheeses, spices, rotten wood, smoke from various types of wood, manure, molds, disinfectants and detergents, varnishes, enamels, etc.

Despite the differences in the responses of the subjects to odors, there is a typical response of subjects of the same age and sex.

Children up to fifteen of both sexes: There is a positive response to camomile, mint, melting snow, and freshly mown grass. Children, after several hours in a chamber filled with one of these smells, solved problems (corresponding to their age) much better than those without the smell; they though faster, and were able to reason better.

The smell of resin, lime in flower, fresh dough, hay, and honey, refreshed women and subjects of both sexes younger than 35. The smell of conifers, fresh apples, lavender, sea salt, rushes and thyme refreshed $80 \%$ of the subjects. Some subjects were even refreshed by the smell of smoke, burning wood, roasted potatoes, gunpowder, and roast meat.

Men and women of all ages: The smell of roses and pansies, the smell of fresh currants, oranges and lemons stimulated pleasant sensations, an appetite for life, an eagerness to work. The smell of narcissi and violets produced a calming effect, and even a sentimental mood. Old people recalled their youth; other people thought about their loved ones; some subjects remembered pleasant melodies. The smell of jasmine, lilac and reseda stimulated feelings of calm and relaxation, a pleasant condition of inactivity.
Shopping activity can be stimulated by smells. According to the German consumer association, about ten thousand hypermarkets and small shops have already used suitable smells to stimulate consumers to more intensive shopping. A new term has been introduced: AIR DESIGN. From the statistics it is really evident that in rooms with an appropriate smell consumers spend $16 \%$ more time, shopping increases by $15 \%$, and turnover by $6 \%$. When asked on leaving the shop, the consumers often responded that had bought goods they did not need and purchased them from some unknown internal incentive.

German MERCEDES and BMW car showrooms favor the smell of the leather of new seats, and DEUTSCHE BANK offices, WEMPE jewellers and HOLIDAY hotels prefer perfumes used during gala occasions (theatre, a concert or a ball). Deutsche Bank even claims that its secret special smell composition creates an atmosphere of confidence and assurance in bank offices.

Fruit and vegetable shops have successfully used the smell of lemons, which induces a feeling of cleanliness and freshness of the goods. Boutiques change the smell in their ladies' department according to the time of year.

\section{Odor microclimate level assessment}

The basic criteria for odor microclimate level assessment, if there is no special source of agents in the room, are carbon dioxide $\left(\mathrm{CO}_{2}\right)$ and total volatile organic compound (TVOC) concentration in the building interior.

Other criteria are derived from these basic criteria: outdoor air rate per person (prescribed in most countries), olf and decipol (recommended in the European Union) and the newest units called decicarbdiox (dCd) and decitvoc (dTv).

\subsection{Carbon dioxide $\mathrm{CO}_{2}$}

For a long time, the odor microclimate has been evaluated on the basis of $\mathrm{CO}_{2}$ concentration and its limit value of 1000 ppm, introduced by von Pettenkofer (1818-1901 Professor at the University in Munich), which is used to determine the minimum amount of fresh air $\left(25 \mathrm{~m}^{3} / \mathrm{h}\right)$ per person. $\mathrm{CO}_{2}$ is the most important biologically active agent whose production is proportional to the human metabolic ratio. There are many limit values of $\mathrm{CO}_{2}$ concentration at present (see Table 1), but the Pettenkofer value is still widely used, and it is a starting point for the prescribed limits in most developed countries.

According to EUR 14449 EN (Report No. 11, Guidelines for Ventilation Requirements in Buildings, Brussels, Luxemburg 1992), recommended regulation of European Union, $25 \mathrm{~m}^{3} / \mathrm{h}$-person is also prescribed for the maximum of $20 \%$ of dissatisfied people within a building interior. According to US BSR/ASHRAE Standard 62-1989R Ventilation for Acceptable Indoor Air Quality the following basic values should be respected:

a) for nonadapted persons $7.5 \mathrm{l} / \mathrm{s} \cdot$ person $\left(27 \mathrm{~m}^{3} / \mathrm{h} \cdot\right.$ person), b) for adapted persons only $2.5 \mathrm{l} / \mathrm{s} \cdot$ person $\left(9 \mathrm{~m}^{3} / \mathrm{h} \cdot\right.$ person).

The value for adapted persons was introduced here for the first time in the world. It is the result of a short-time odor adaptation - see section 2 The impact of odors on man. 
Table 1: Limits for $\mathrm{CO}_{2}$ concentrations in a building interior

\begin{tabular}{|c|c|c|c|c|c|}
\hline \multirow[t]{2}{*}{ No. } & \multicolumn{3}{|c|}{ Limit } & \multirow[t]{2}{*}{ Value } & \multirow[t]{2}{*}{ Source } \\
\hline & {$\left[\mathrm{mg} \mathrm{m}^{-3}\right]$} & [ppm] & {$[\mathrm{dCd}]$} & & \\
\hline 1 & 875 & 485 & 0 & Threshold & $5.8 \%$ dissatisfied \\
\hline 2 & 1080 & 600 & 8 & USAF warning & USAF Armstrong Laboratory (1992) \\
\hline 3 & 1110 & 615 & 9 & Un Asthm. optimal & $10 \%$ dissatisfied unadapted \\
\hline 4 & 1440 & 800 & 20 & OSHA warning & OSHA: Federal Register (1994) \\
\hline $5 \mathrm{a}$ & 1800 & 1000 & 28 & Optimal limit & Pettenkofer (1858) \\
\hline $5 \mathrm{~b}$ & 1800 & 1000 & 28 & Acceptable limit & BSR ASHRAE 62-1989R (1989) \\
\hline $5 c$ & 1800 & 1000 & 28 & Opt. long-term & $\begin{array}{l}\text { WHO/EURO: Air Quality Guidelines } \\
\text { EUR } 14449 \text { EN (1992) }\end{array}$ \\
\hline $6 a$ & 1825 & 1015 & 29 & Un optimal limit & $20 \%$ dissatisfied unadapted \\
\hline $6 b$ & 1825 & 1015 & 29 & Un Asthm. admissible & \\
\hline $6 c$ & 2000 & 1110 & 32 & $\begin{array}{l}\text { Concentration of no concern } \\
\text { for non-industrial buildings }\end{array}$ & WHO; Levy (1992) \\
\hline $7 \mathrm{a}$ & 2160 & 1200 & 35 & Opt. short-term & $\begin{array}{l}\text { WHO/EURO: Air Quality Guidelines } \\
\text { EUR 14449 EN (1992) }\end{array}$ \\
\hline $7 \mathrm{~b}$ & 2200 & 1225 & 36 & Ad asthm. optimal & $10 \%$ dissatisfied adapted \\
\hline 8 & 2830 & 1570 & 46 & Un admissible & $30 \%$ dissatisfied unadapted \\
\hline $9 \mathrm{a}$ & 4350 & 2420 & 63 & Ad optimal limit & $20 \%$ dissatisfied adapted \\
\hline $9 \mathrm{~b}$ & 4350 & 2420 & 63 & Ad asthm. admissible & (BSR/ASHRAE Standard 62-1989R) \\
\hline $10 \mathrm{a}$ & 5035 & 2800 & 68 & Limit for direct gas-fired air heaters & BS 5990: 1981 of British Standard Institution \\
\hline $10 \mathrm{~b}$ & 5035 & 2800 & 68 & Limit for direct gas-fired air heaters & BS 6230: 1982 of British Standard Institution \\
\hline $11 \mathrm{a}$ & 6300 & 3500 & 77 & Long-term acceptable & Env. Health Directorate, Canada (1989) \\
\hline $11 b$ & 7000 & 3890 & 81 & $\begin{array}{l}\text { Concentration of concern } \\
\text { for non-industrial buildings }\end{array}$ & WHO; Levy (1992) \\
\hline $11 \mathrm{c}$ & 7360 & 4095 & 83 & Ad admissible & $30 \%$ dissatisfied adapted \\
\hline $12 \mathrm{a}$ & 9000 & 5000 & 91 & Long-term exposure limit (8 h) & Guidance Note EH 40/90 from HSE of GB \\
\hline $12 b$ & 9000 & 5000 & 91 & $\begin{array}{l}\text { Average concentration for industrial } \\
\text { and non-industrial buildings }\end{array}$ & $\begin{array}{l}\text { Commission de la Sante et } \\
\text { de la Securite du Travail }\end{array}$ \\
\hline $12 \mathrm{c}$ & 9000 & 5000 & 91 & Long-term tolerable & USSR space research (SBS range ends) \\
\hline $13 \mathrm{a}$ & 18000 & 10000 & 118 & $\begin{array}{l}\text { Maximum allowable concentration } \\
\text { for ind. and non-ind. buildings }\end{array}$ & $\begin{array}{l}\text { Commission de la Sante et } \\
\text { de la Securite du Travail }\end{array}$ \\
\hline $13 \mathrm{~b}$ & 18000 & 10000 & 118 & Short-term tolerable & USSR space research \\
\hline $14 \mathrm{a}$ & 27000 & 15000 & 134 & Short-term tolerable & Toxic range begins \\
\hline $14 \mathrm{~b}$ & 27000 & 15000 & 134 & Short-term exposure limit (10 min) & Guidance Note EH 40/90 from HSE of GB \\
\hline
\end{tabular}

un, unadapted persons; ad, adapted persons; asthm., asthmatic persons

In practice, monitoring the $\mathrm{CO}_{2}$ level for the purpose of controlling fresh air supply has proved satisfactory for lecture theatres, halls, cinemas, theatres and similar spaces where the load imposed by occupants can vary rapidly.

\subsection{Total of volatile organic compounds TVOC}

Although $\mathrm{CO}_{2}$ is a good indicator of the perceived air quality by the people present, it can sometimes be an unsuit- able indicator: it does not represent perceived sources of air contamination such as building materials and fittings, especially carpets and other floor covering materials that producing VOC. The complex of these substances is called TVOC. Various TVOC limits are listed in Table 2.

For this reason Fanger [3] proposed a new system based on units known as the "olf" and the "decipol". One olf is the odor pollution produced by one standard person - an aver- 
Table 2: Limits for TVOC concentrations in a building interior

\begin{tabular}{|c|c|c|c|c|}
\hline \multirow[t]{2}{*}{ No. } & \multicolumn{2}{|c|}{ Limit } & \multirow[t]{2}{*}{ Value } & \multirow[t]{2}{*}{ Source } \\
\hline & {$\left[\mu \mathrm{g} \cdot \mathrm{m}^{-3}\right]$} & $\mathrm{dTV}$ & & \\
\hline 1 & 50 & 0 & Threshold & $5.8 \%$ dissatisfied ( 1.0 by Yaglou psycho-physical scale) \\
\hline 2 & 85 & 12 & Un asthm. optimal & $10 \%$ dissatisfied unadapted, EUR 14449 EN (1992) \\
\hline $3 \mathrm{a}$ & 200 & 30 & Un optimal limit & $20 \%$ dissatisfied unadapted, EUR 14449 EN (1992) \\
\hline $3 \mathrm{~b}$ & 200 & 30 & Un asthm. admissible & $\begin{array}{l}\text { Old dwelling houses } \\
\text { Old office building }\end{array}$ \\
\hline 4 & 250 & 35 & Ad. asthm. optimal & $10 \%$ dissatisfied adapted \\
\hline 5 & 300 & 39 & Target guideline & Seifert (1990) \\
\hline 6 & 360 & 43 & Un admissible & $\begin{array}{l}30 \% \text { dissatisfied unadapted, EUR } 14449 \text { EN (1992) } \\
\text { New dwelling houses } \\
\text { New office buildings }\end{array}$ \\
\hline $7 \mathrm{a}$ & 500 & 50 & Level of concern & $\begin{array}{l}\text { National Health and Medical Research Council of Australia, } \\
\text { Dingle and Murray (1993) }\end{array}$ \\
\hline $7 \mathrm{~b}$ & 580 & 53 & Ad optimal limit & $20 \%$ dissatisfied adapted \\
\hline $7 \mathrm{c}$ & 580 & 53 & Ad asthm. admissible & \\
\hline 8 & 1040 & 66 & Ad admissible & $30 \%$ dissatisfied adapted \\
\hline $9 \mathrm{a}$ & 3000 & 89 & Long-term tolerable & SBS range ends \\
\hline $9 \mathrm{~b}$ & 3000 & 89 & Multifactorial exposure range limit & Molhave (1990) \\
\hline $10 \mathrm{a}$ & 25000 & 135 & Short-term tolerable & Toxic range begins \\
\hline $10 \mathrm{~b}$ & 25000 & 135 & Discomfort range limit & Molhave (1990) \\
\hline
\end{tabular}

un, unadapted persons; ad, adapted persons; asthm., asthmatic persons

Table 3: Outdoor air rates per person according to EUR 14449 EN

\begin{tabular}{|c|c|c|c|c|}
\hline \multirow{2}{*}{$\begin{array}{c}\text { Quality level } \\
\text { (categories) }\end{array}$} & \% dissatisfied & decipol & \multicolumn{3}{c|}{ Required air rate } \\
\cline { 2 - 5 } & 10 & 0.6 & $1 / \mathrm{s}$ olf & $\mathrm{m}^{3} / \mathrm{h} \cdot \mathrm{person}$ \\
\hline A & 20 & 1.4 & 7 & 58 \\
\hline B & 30 & 2.5 & 4 & 25 \\
\hline C & & & 16 & 14 \\
\hline
\end{tabular}

age adult sitting person having thermal comfort during office or similar nonindustrial work, whose hygienic standard is 0.7 baths per day. One decipol is the air pollution by one standard person (one olf) ventilated by an air volume of $10 \mathrm{l} / \mathrm{s}\left(36 \mathrm{~m}^{3} / \mathrm{h}\right)$ of clean air. On the basis of the estimated air quality within an interior in decipols the necessary outdoor air quantity can be calculated following the instructions in recommended EUR $14449 \mathrm{EN}$; for some basic values see Table 3. There are certain obvious problems with this system, as waspointed out by [12], [8] and especially by [13]. Thus these units were not accepted for the BSR/ASHRAE Standard 62-1989R. For example, the units are presented as a system of overall indoor air quality valuation, although they are based on odor perception. Thus, e.g., air polluted with radon is O.K., because radon has no smell.

\section{3 $\mathrm{CO}_{2}$ plus $\mathrm{TVOC}$}

The most progressive systems - US ASHRAE Standard 62 - 1989R and a new European standard, using decibel units dTv and dCd, are based on two basic criteria: $\mathrm{CO}_{2}$ and TVOC. Carbon dioxide is a criterion for odor air pollution in the presence of people, while TVOC is a criterion for odor air pollution by building materials and fittings. The necessary outdoor air rate for ventilation is the sum of the two air quantities, calculated on basis of $\mathrm{CO}_{2}$ and TVOC.

ASHRAE Standard $62-1989 \mathrm{R}$ is a complex of tables in the main part (Prescriptive Requirements) (e.g., see Table 4). The minimum outdoor air rates, first for people ( $1 / \mathrm{s} \cdot$ person), second for TVOC production by building and other materials $\left(\mathrm{l} / \mathrm{s} \cdot \mathrm{m}^{2}\right.$ floor $)$ are listed directly in the tables. The minimum 
Table 4: Minimum requirements for ventilation (6.1a in ASHRAE 62-1989R)

\begin{tabular}{|l|c|c|}
\hline \multirow{2}{*}{\multicolumn{1}{|c|}{ Space }} & \multicolumn{2}{c|}{ Prescriptive requirements } \\
\cline { 2 - 3 } & $\begin{array}{c}\text { People } \\
\mathrm{R}_{\mathrm{P}} \\
\mathrm{l} / \mathrm{s} \cdot \text { person }\end{array}$ & $\begin{array}{c}\text { Building } \\
\mathrm{R}_{\mathrm{B}} \\
\mathrm{l} / \mathrm{s} \cdot \mathrm{m}^{2}\end{array}$ \\
\hline Educational facilities & & 0.70 \\
\hline Day care (through age 4) & 3.5 & 0.70 \\
\hline Classrooms (ages 5-8) & 3.0 & 0.55 \\
\hline General classrooms & 3.0 & 0.55 \\
\hline Lecture classroom & 3.0 & 0.35 \\
\hline Lecture hall (fixed seats) & 2.5 & 1.85 \\
\hline Art classroom & 5.0 & 2.85 \\
\hline Science laboratories & 3.5 & 1.85 \\
\hline Wood/metal shop & 4.0 & 0.70 \\
\hline Media center & 3.0 & 0.70 \\
\hline Music/theater/dance & 7.0 & 0.55 \\
\hline Multi-use assembly hall & 3.0 & \\
\hline
\end{tabular}

outdoor air rate for people, in contradiction to other regulations, is valid for adapted persons (the basic value is $2.5 \mathrm{l} / \mathrm{s} \cdot$ person, i.e., $9 \mathrm{~m}^{3} / \mathrm{h}$. person only). For unadapted persons (e.g., coming from outdoors, i.e., visitors) all values must be increased by $5 \mathrm{l} / \mathrm{s} \cdot$ person, i.e., by $18 \mathrm{~m}^{3} / \mathrm{h} \cdot$ person. Thus the total value for people is $27 \mathrm{~m}^{3} / \mathrm{h} \cdot$ person, which does not differ too much from Pettenkofer's value of $25 \mathrm{~m}^{3} / \mathrm{h} \cdot$ person.

The newest valuation system of the odor microclimate uses decibel units derived similarly as decibel units for noise: the new units are modified Briggs' logarithms of concentrations (so called odor levels) of $\mathrm{CO}_{2}$ and TVOC measured in the investigated room and related to threshold values (the weakest odors that can be detected) [9].

Odor level based on $\mathrm{CO}_{2}$ concentration is defined by the equation:

$L_{\text {odor }(\mathrm{CO} 2)}=90 \log \frac{\rho_{\mathrm{iCO}_{2}}[\mathrm{ppm}]}{485} \quad[$ decicarbdiox $],[\mathrm{dCd}](1)$

Odor level based on TVOC concentration is defined by the equation:

$L_{\text {odor(TVOC) }}=50 \log \frac{\rho_{\text {iTVOC }}\left[\mu \mathrm{g} / \mathrm{m}^{3}\right]}{50}[$ decitvoc $],[\mathrm{dTv}](2)$

where $\rho_{\mathrm{i}}$ are the measured concentrations in a building interior.

Optimal, admissible, long-term and short-term tolerable values and their ranges are presented in Figs. 5 and 6. Optimal values correspond to the percentage of dissatisfied per- sons $\mathrm{PD}=20 \%$ (for asthmatics $\mathrm{PD}=10 \%$ ), admissible values $\mathrm{PD}=30 \%$, long-term tolerable values determine the range for the so called "sick building syndrome" (SBS). All these values are given for adapted and nonadapted persons.

The main advantages of the new proposed evaluation system can be summed up as follows:

1. The undoubted benefit of using the decibel scale is that it gives a much better approximation to human perception of odor intensity than to the $\mathrm{CO}_{2}$ and TVOC concentration scales. This is because the human olfactory organ (see Jokl 1989) reacts to a logarithmic change in level which corresponds to the decibel scale.

2. The new decicarbdiox and decitvoc values also fit very well with the $\mathrm{dB}$ values for sound, e.g. the optimal odor value of $30 \mathrm{~dB}$ corresponds to the ISO Noise Rating Acceptable Value NR 30 for libraries and private offices. They can therefore be compared to each other.

3. It is possible, by comparing $\mathrm{dCd}$ and $\mathrm{dTv}$ values, to estimate which component - $\mathrm{CO}_{2}$ or TVOC - plays a more important role, and hence which sources of contamination are more serious.

4. The dCd and dTv units can be estimated by direct measurements of TVOC and $\mathrm{CO}_{2}$ concentrations - instruments can be calibrated directly in the new units.

5. The dCd and dTv units, as indoor air quality criteria, allow an optimal range to be defined and a corresponding optimal ventilation rate to be estimated for unadapted and adapted persons. 


\section{OPTIMAL, ADMISSIBLE AND TOLERABLE VALUES}

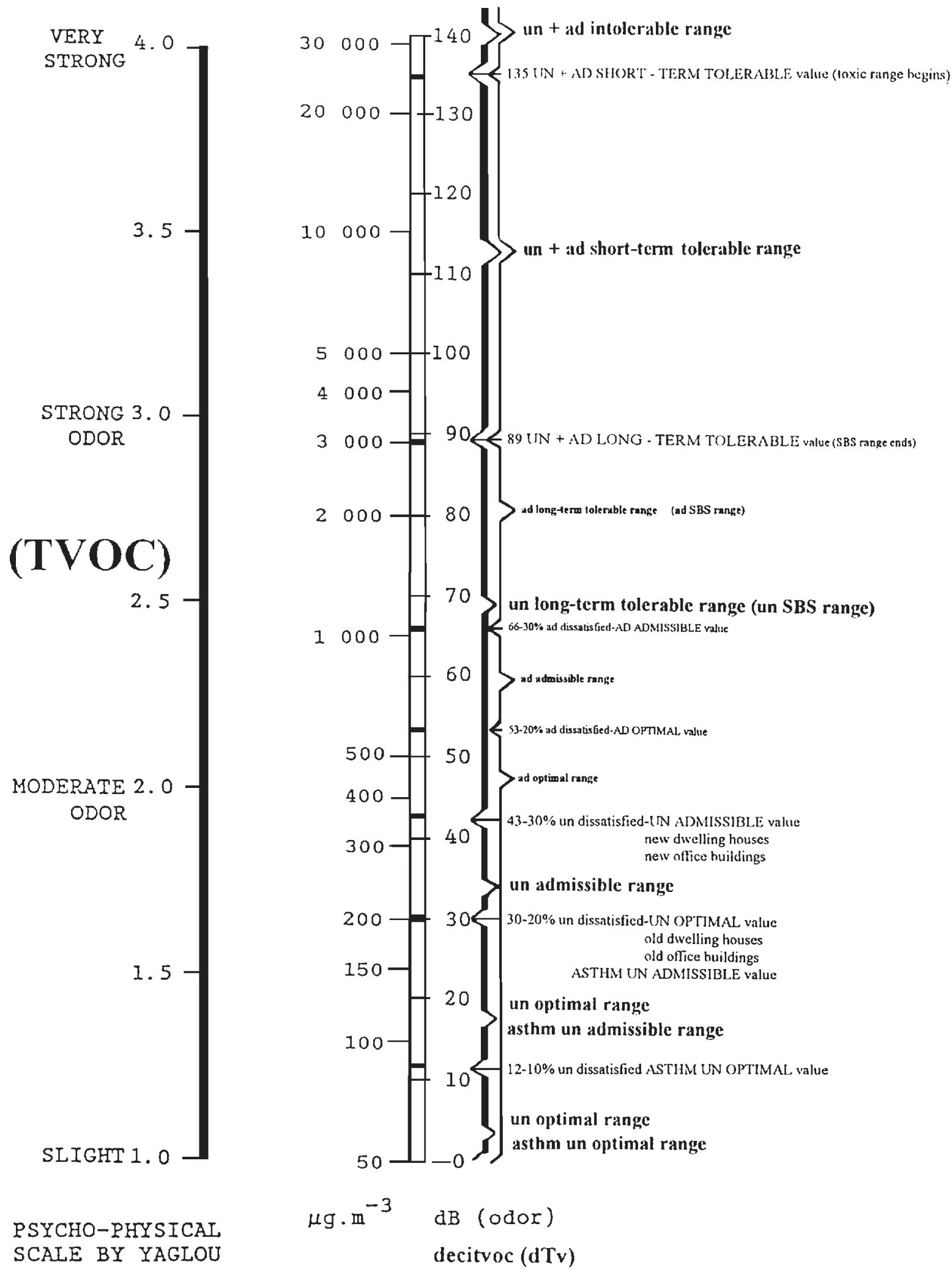

Fig. 5: Optimal, admissible and tolerable limits for $\mathrm{CO}_{2}$ in a building interior

6. The units allow the SBS range to be defined (corresponding to the long-term tolerable range) and corresponding long-term tolerable ventilation rates to be estimated. 


\section{OPTIMAL, ADMISSIBLE AND TOLERABLE VALUES}

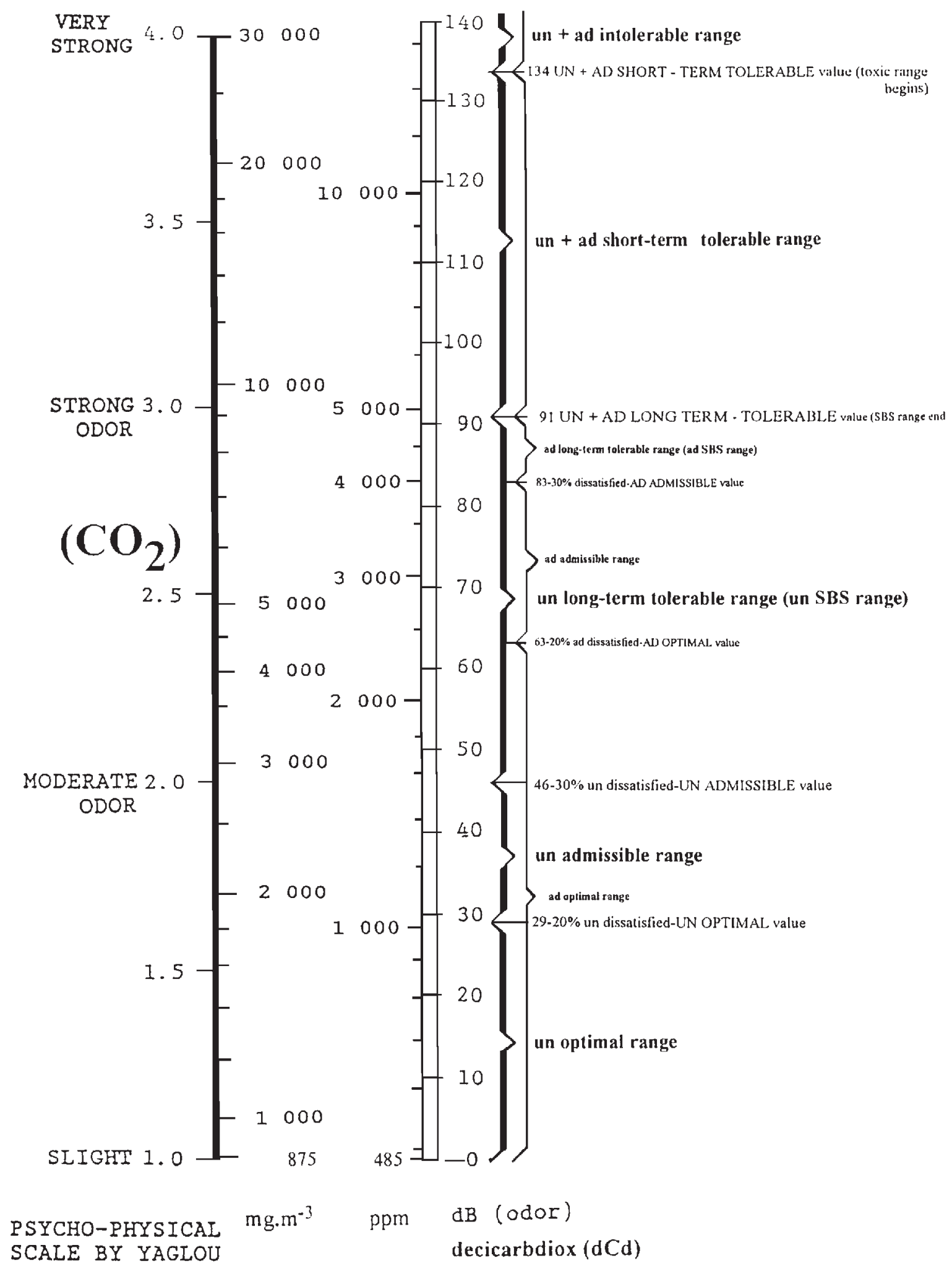

Fig. 6: Optimal, admissible and tolerable limits for TVOC in a building interior

7. The units allow the efficiency of air cleaners (and other indoor air-improving measures, e.g. the use of less pollut- ing building materials) to be expressed, i.e., what is the decrease in air contamination after application. 


\section{References}

[1] BSR/ASHRAE Standard 62-1989R Ventilation for Acceptable Indoor Air Quality.

[2] EUR 14449 EN. Quidelines for Ventilation Requirements in Buildings. Report No. 11, Commission of EC, Luxembourg 1992.

[3] Fanger, P. O.: Introduction of the olf and the decipol units to quantify air pollution perceived by human indoors and outdoors. Energy and Buildings, Vol. 12, No. 1/1988, p. 1-6.

[4] Hicks, J. et al: Building Bake-Out During Commissioning: Effects on VOC Concentration. In: Proc. of the Fifth Int. Conference on Indoor Air Quality and Climate, Vol. 3, Toronto (Canada), 1990.

[5] IAQU. Odor evaluation as an investigative tool. Indoor Air Quality Update, 1991, p. 10-13.

[6] Jokl, M.: Microenvironment: The Theory and Practice of Indoor Climate. Springfield (Illinois - U.S.A): Thomas Publisher, 1989, p. 416.

[7] Jokl, M.: The Theory of Indoor Environment of Buildings. Czech. Praha: Vydavatelství ČVUT, 1993, p. 261.

[8] Jokl, M. V., Leslie, G. B., Levy, L. S.: New approaches for the determination of ventilation rates: the role of sensory perception. Indoor Environment, 1993, Vol. 2, No. 2 p. 143-148.

[9] Jokl, M. V.: Evaluation of indoor air quality using the decibel concept. Int. J. of Environmental Health Research, 1997, Vol. 7, No. 4, p. 289-306.
[10] Kaiser, E. R.: Odor and its measurement. In: Air Pollution, Academic Press, 1962, p. 50-527.

[11] Mc Burney, D. H., Levine, J. M., Cavanaugh, P. H.: Psychological and social ratings of human body odor. Personality and Social Psychology Bulletin, 1977, No. 3, p. 135-138.

[12] Oseland, N. A.: A review of odor research and the new units of perceived air pollution. BRE, Watford, 1993, p. 24.

[13] Parine, N.: The use of odor in setting ventilation rates. Indoor Environment, 1994, Vol. 3, No. 3, p. 87-95.

[14] Pettenkofer, M.: Über den Luftwechsel in Wohngebauden. München, 1858.

[15] The Human Body. Bratislava: GEMINI, 1992.

Miloslav V. Jokl, Ph.D., Sc.D, University Professor phone: +420224354432

fax: +420233339961

e-mail: miloslav.jokl@fsv.cvut.cz

Czech Technical University in Prague

Faculty of Civil Engineering

Thákurova 7

16629 Prague 6, Czech Republic 